\title{
“ESTA ESCRITA DE MULHERES ESTÁ MARCADA PELO GRITO LONGAMENTE SILENCIADO, QUE ATRAVESSOU PORÕES, CHIBATAS, SACRISTIAS E SALÕES E SÓ AGORA OUSA SOLTAR"
} ENTREVISTA A VERA DUARTE,
ESCRITORA CABO-VERDIANA

\author{
Iris Maria da Costa Amâncio \\ (Universidade Federal Fluminense)
}

Iris Amâncio: Para você, qual a importância da representação ficcional nas relações de gênero?

Vera Duarte: Através da representação ficional, conseguimos projetar o salto qualitativo por que lutamos para as relações de género e que, globalmente falando, tardam a chegar, com o objetivo de impelir a humanidade a abraçar essa causa. A desconstrução das relações de género, baseadas no modelo patriarcal e machista, faz-se lentamente e, mais lentamente ainda, a construção da nova relação baseada na igualdade e liberdade que preconizamos. A representação ficional surge, assim, como um modelo a perseguir e atingir e tem também um relevante papel catártico.

As mulheres utilizam a escrita para fazer representar as relações de género que ambicionam, denunciando as práticas negativas e clamando por novos modelos mais consentâneos com os direitos das mulheres já proclamados, extravasando, assim, o real imperfeito para poder fazer do ideal um lugar-comum.

IA: Comente sobre as diferenças (ou não) de performance, na escrita literária, entre escritores e escritoras, seja em termos temático-discursivos ou estéticos.

VD: Acredito que a emergência da voz das mulheres na escrita literária trouxe um enriquecimento enorme à própria escrita, seja em termos estéticos seja temáticos. 
Primeiro, com o inegável adensar do tratamento das personagens femininas desde o seu hábito externo à dimensão mais profunda do seu sentir, consciente e do inconsciente. Depois, aprofundando cada vez mais no terreno da libido das emoções e dos sentimentos. Sobretudo, com uma linguagem nova e uma nova roupagem no uso das palavras.

Eu ousaria dizer que a escritura feminina inaugurou um novo universo na literatura, em que ela fala de si mesma, dos seus amores e desamores, afetos e frustrações, atravessando os diversos níveis dos personagens desde os mais superficiais aos mais profundos. [No caso de Cabo Verde] As mulheres falam do heróico quotidiano, da casa e domesticidade, do carregar da água, das gravidezes, das pancadas, dos desafios e da participação na vida pública numa hermenêutica do quotidiano crioulo, em que a mulher aparece como protagonista verdadeira e não mais como "protagonista" em estórias de homens. Elas retratam a imperfeição e a riqueza do real, ultrapassando o êxtase criativo e contemplativo. Sobretudo, elas recriam espaços de construção e crítica e um outro olhar para o social, deslocando-se do nível ideal para o nível real, denunciando hipocrisias e situações-limite.

Para além disso, toda esta escrita de mulheres está marcada pelo grito longamente silenciado, que atravessou porões, chibatas, sacristias e salões e só agora se ousa soltar pois, como profetizou o magnífico poeta francês Arthur Rimbaud nos idos de 1871 "quando for quebrada a infinita servidão da mulher, quando ela viver por si e para si, o homem - até agora, abominável - deixá-la-á em liberdade e ela será poeta, ela também..."

Pois, embora Platão, no século V A.C., já tivesse afirmado, pela boca de Sócrates em seus diálogos, que as ocupações destinadas aos homens, tanto ligadas à guerra como relativos a outros aspetos da vida, deveriam se estender igualmente às mulheres., sabemos todos que esta é uma realidade que só começou a ganhar corpo nos finais do século XIX e início do século XX com a conquista dos direitos civis e políticos pelas mulheres.

IA: Qual conceito de mulher cabo-verdiana você procura representar em seus textos literários?

VD: Refletindo sobre esta questão, constato que a mulher cabo-verdiana que "essencialmente" vem sendo representada na minha escrita tem muito a ver com as mulheres com quem me tenho relacionado mais de perto, seja a nível familiar, seja a nível profissional. Ela é normalmente uma mulher trabalhadeira, que cuida da casa e dos filhos e, muitas vezes, também trabalha fora de casa. É uma mulher que, enquanto jovem, vai, muitas vezes, tendo sucessivos relacionamentos amorosos, de que resultam filhos que normalmente ela acaba por criar sozinha. Isto faz dela uma mulher chefe-de-família no sentido literal do termo, de uma família monoparental.

Contudo, ela ainda depende bastante do pai-de-filho, marido, companheiro, amante ou namorado, sobretudo do ponto de vista económico, mas também social. 
Por isso mesmo, ela continua sendo muito vítima de violência doméstica, seja física, seja psicológica, pois a "supremacia" do homem no lar é ainda uma realidade, embora já em ritmo de desconstrução. Durante muito tempo, foi uma mulher "resignada", mas cada vez mais esta característica está dando lugar a uma mulher alegre, combativa e ambiciosa, que procura ser feliz, nem que seja através dos filhos.

IA: Poderíamos falar em especificidades dessa mulher cabo-verdiana que você ficcionaliza?

VD: Penso que a característica mais marcante da mulher cabo-verdiana é ela ser extremamente dedicada aos filhos. Procura dar-lhes o melhor que puder e, para isso, desdobra-se a trabalhar se for necessário. Muitas vezes, cria sozinha os filhos que tem, de um ou mais relacionamentos, sem o apoio dos pais-de-filho.

Ela é também uma mulher que procura não depender economicamente do homem, seja marido, companheiro ou simplesmente pai-de-filho. Por essa via, ela busca a suficiência económica através de vários tipos de trabalhos, seja em casa, seja fora de casa, embora seja ainda o rosto da pobreza em Cabo Verde.

Mas, cada vez mais, ela busca a sua emancipação e a sua afirmação e é sobretudo essa mulher que, instintivamente, eu retrato em meus textos, uma mulher que pode "quebrar a cara", mas levanta a cabeça e dá a volta por cima.

Nos meus escritos, muitas vezes de forma subliminar, apelo a mulher à insubmissão, à indignação e à construção de um futuro de emancipação e empoderamento.

IA: Há alguma personagem feminina que você considera de maior visibilidade em sua obra?

VD: A Marina, de A Candidata, parece-me ser, indubitavelmente, a personagem de maior visibilidade em tudo o que já escrevi. Talvez por ela concretizar muito do que considero ser uma mulher de exceção, sem perder as características da mulher comum, que qualquer uma pode ser. Ela representa a mulher que rompe com um passado patriarcal e machista, que vai à luta e aceita todos os desafios que o processo de emancipação comporta. Que ousa candidatar-se à mais alta magistratura da nação, sem deixar de ser uma comum cabo-verdiana, que teve filho sem estar casada, que se tornou esposa e mãe e sempre trabalhando fora.

A sua trajetória de vida é fortemente paradigmática das mulheres do final do século XX, pelo menos no mundo ocidental.

IA - Quais escritoras e personagens femininas mais impactaram o seu processo de escrita literária e que por quê?

VD - Muitas mulheres impactaram o meu processo de escrita literária a começar por Florbela Espanca, Safo, Virgínia Wolf, Simone Beauvoir ou Mariama Bá. 
E, em termos de personagens, eu realçaria a personagem autobiográfica de Virginia Woolf em As Ondas, a personagem também autobiográfica de Mariama Bá em Une si longue lettre e, mais lá atrás, mulheres como as personagens femininas de $O$ Monte dos Vendavais [O morro dos ventos uivantes] de Emely Bronte, a Anna Karenina do romance homólogo de Leo Tolstoy ou, ainda, a Madame Bovary do também romance homólogo de Gustave Flaubert.

São personagens que me marcaram decisivamente pelo que elas representam de corte radical e epistemológico com o passado de submissão, inferiorização, machismo, invisibilidade, violência e vitimização da mulher.

Recebido para publicação em 03/10/2012 Aprovado em 19/02/2013 